\title{
PRODUCT BRANDING NATA DE LEGEN DUSUN SHOBEROH DESA DALEGAN KECAMATAN PANCENG KABUPATEN GRESIK
}

\author{
I'Lamatul Laili \\ Universitas Islam Negeri Sunan Ampel Surabaya \\ laili@gmail.com
}

\begin{tabular}{l}
\hline \hline Article Info \\
\hline Article history: \\
Received 4 Februari 2019 \\
Accepted 7 Maret 2019 \\
Published 10 April 2019 \\
\hline
\end{tabular}

Keyword:

Product branding, Nata de Legen, Kelompok Legen Shoberoh, Komunikasi Pemasaran Terpadu.

\section{Abstract}

This article discusses the process of product branding "Nata de Legen" conducted by the Legen Shoberoh Group (KLS) and the media used. This research uses a qualitative approach. The aim is to describe the product branding process and the media used by KLS in marketing Nata de Legen. The results showed that the product branding carried out by KLS includes four stages; recognition, attracting consumers, marketing, and customer loyalty. In product branding, KLS optimizes services and provides empathy to customers with personal communication. The media used in the product branding process are social media Facebook and Whatsapp, then the point of purchase, namely the Dalegan White Sand tour.

Artikel ini membahas proses product branding "Nata de Legen" yang dilakukan oleh Kelompok Legen Shoberoh (KLS) dan media yang digunakan. Penelitian ini menggunakan pendekatan kualitatif. Tujuannya adalah mendeskripsikan proses product branding dan media yang digunakan oleh KLS dalam pemasaran Nata de Legen. Hasil penelitian menunjukkan, bahwa product branding yang dilakukan oleh KLS meliputi empat tahap; pengenalan, menarik konsumen, pemasaran, dan kesetian pelanggan. Dalam product branding, KLS mengoptimalisasi pelayanan dan memberi empati kepada pelanggan dengan komunikasi personal. Media yang digunakan dalam proses product branding adalah media-media sosial Facebook dan Whatsapp, kemudian titik penjualan, yaitu wisata Pasir Putih Dalegan. 


\section{Pendahuluan}

Indonesia, merek mulai berkembang sejak peralihan antara abad 19 dan abad 20. Pada masa penjajahan Belanda tersebut, sudah banyak produk indonesia, seperti jamu, rokok, kecap, kopi dan teh menggunakan logo atau gambar sebagai merek. Mudah di pahami mengapa logo yang dipilih sebagai bentuk merek. Tentu saja itu mempermudah konsumen buta huruf dalam mengenali merek perusahaan. Hanya saja, tujuan pemakaian merek pada masa itu lebih difokuskan sebagai tanda untuk mengidentifiksai produsen, perancang dan atau penyedia jasa spesifik. ${ }^{1}$

Merek berkaitan erat dengan produk dan perusahaan/organisasi, namun kelanggengan merek tidak identik dean kemampuan survival jangka panjang produk dan perusahaan. Dalam undangundan merek No.15 tahun 2001pasal 1 ayat 1, merumuskan bahwa "Tanda yang berupa gambar, nama, kata, huruf-huru, angkaangka, susunan warna, ata kombinasi dari unsur unsur tersebut yang memiliki daya pembeda dan digunakan dalam kegiatan perdagangan barang atau jasa”. Dalam rancangan undang-undang merek terbaru, cakupan defnisi merek diperluas hingga mencakup pula bentuk, suara, hologram dan aroma. Kedua definisi ini menekankan tujuan identifikasi dan diferensiasi.

Branding memiliki fungsi tertentu. Dimana dengan melakukan sebuah branding akan menjadi pembeda antara produk yang satu dengan yang lainnya. Produk akan memiliki perbedaan

1 Fandi Tjiptono, Branding \& Brand Longevity Indonesia, (Yogyakarta: CV. Andi Offset, 2014), 93. dibandingkan pesaing lainnya, Sehingga suatu produk dapat dibedakan dengan mudah. Dengan begitu melakukan branding juga akan membentuk citra atau keyakinan mengenai kualitas atau prestige suatu produk yang melekat.Branding juga memiliki fungsi sebagai promosi dan daya tarik. Dimana dengan melakukan branding suatu produk akan memiliki daya tarik tersendiri dengan menampilkan unsurunsur dalam branding. Fungsi yang lain dari branding ini adalah brand mampu mengendalikan pasar terkait produk dengan mudah.

Dalam ruang lingkup pemasaran, produk dapat dikaitkan dengan produk fisik. Namun produk juga dapat dilihat dari gagasan, misalnya untuk menghilangkan kebiasaan membuang sampah di sungai dalam rangka membersihkan kota jakarta dan kegiatan kemasyarakatan lain. Demikian produk dapat dilihat dari berbagai sudut pandang. ${ }^{2}$ Menurut Morissan, Pemasaran mencakup sejumlah kegiatan seperti riset pemasaran, penentuan harga, atau perencanaan produk. Pemasaran pada dasarnya mencakup segala kegiatan tersebut, namun demikian pemasaran ternyata lebih dari sekedar kegiatan-kegiatan tersebut. Berbagai kegiatan seperti pembujukan, promosi, publikasi, semuanya adalah kegiatan pemasaran. Namun begitu pemasran bukanlah semata-mata kegiatan seperti menjual dan mempromosikan sesuatu. Pemasaran adalah suatu konsep yang menyangkut suatu sikap mental, suatu cara

${ }^{2}$ Ari Setyiyaningrum, Jusuf Udaya \& Efendi, Prinsip-prinsip Pemasaran, (Yogyakarta: ANI Yogyakarta, 2015), 88-89 
yang membimbing anda melakukan sesuatu yang tidak selalu menjual benda tetapi juga menjual gagasan, karier, tempat, undang-undang, jasa, hiburan dan kegiatan-kegiatan Nirlaba. ${ }^{3}$

Ruang lingkup pemasaran, produk dapat dikaitkan dengan produk fisik. Namun produk juga dapat dilihat dari gagasan, misalnya untuk menghilangkan kebiasaan membuang sampah di sungai dalam rangka membersihkan kota jakarta dan kegiatan kemasyarakatan lain. Demikian produk dapat dilihat dari berbagai sudut pandang. ${ }^{4}$ Pada saat ini banyak sekali berbagai produk-produk makanan dan miuman, terlebih adalah produk instan dengan variasi rasa. Bisnis kuliner sekarang memang bukanlah menjadi hal yang asing untuk dibicarakan. Berbagai usaha kelompok kecil dan besar mulai membuat sebuah produk makanan dan minuman yang begitu digandrungi masyarakat indonesia. Salah satunya adalah minuman dan makanan tradisional, dimana dari proses pemasaran mereka yang unik tidak lagi menjadi hambatan bagi para pengusaha rumahan untuk menjualkan produk mereka sehingga tidak kalah dengan usaha makanan terkenal yang lainnya.

Pada saat ini banyak sekali berbagai produk-produk makanan dan miuman, terlebih adalah produk instan dengan variasi rasa. Bisnis kuliner sekarang memang bukanlah menjadi hal yang asing untuk dibicarakan. Berbagai usaha kelompok kecil dan besar mulai membuat sebuah produk makanan dan minuman

3 Morissan, Periklanan : Komunikasi Pemasaran Terpadu, (Jakarta: Kencana, 2010), 2. yang begitu digandrungi masyarakat indonesia. Salah satunya adalah minuman dan makanan tradisional, dimana dari proses pemasaran mereka yang unik tidak lagi menjadi hambatan bagi para pengusaha rumahan untuk menjualkan produk mereka sehingga tidak kalah dengan usaha makanan terkenal yang lainnya.

Salah satunya di Kabuaten Gresik ini, tepatnya di Dusun Shoberoh Desa Dalegan Kecamatan panceng. Sebagian besar dari penduduk di dusun shoberoh ini mata pencahariannya adalah sebagai petani, selebihnya adalah wiraswasta dan guru. Sebagaimana contoh Petani Legen, legen merupakan minuman khas dari dusun shoberoh yang alami. Legen sendiri adalah hasil dari pohon siwalan. Legen biasanya di jual oleh masyarakat Dusun shoberoh di sepanjang jalan Desa Dalegan tepatnya arah Pantai Pasir Putih Dalegan. Oleh masyarakat dusun, Legen juga diolah menjadi Gula Merah. Legen merupakan minuman yang cepat sekali mengalami fermentasi, sehingga tidak tahan lama jika diminum dalam waktu yang lama. Namun seiring perkembangan zaman, dengan kecanggihan teknologi Legen yang mengalami fermentasi bisa di olah kembali yaitu menjadi produk yang laku jual dan bisa tahan lama dan memiliki nilai ekonomi tinggi, yaitu "Nata De Legen"

Tiga Dosen jurusan Biologi Universitas Negeri Surabaya (UNESA) Dr. Mehanani Tri Asri M. Si., Dr. Nurducha, M. Si., Dra. Evie Ratnasari. memberikan pelatihan dan pendampingan pemanfaatan

${ }^{4}$ Ari Setyiyaningrum, Jusuf Udaya \& Efendi, Prinsip-prinsip, 88-89. 
legen yang tidak laku jual kepada masyarakat. Kegiatan tersebut mendapatkan pendanaan dari skim Program Pengembangan Desa Mitra (PPDM) Kemenristek Dikti. Pelatihan pembuatan nata de legen diawali dengan proses pembuatan stater nata yang berisi Acetobacter xylinum, kemudian membuat nata de legen, pengolahan pasca panen dan pembuatan produk (minuman dan makanan) yang siap dijual serta pemasaran.

Selain itu pengetahuan lain seperti pengawetan produk, managemen usaha dan pembukuan juga dilatihkan. Pelatihan dan pendampingan dari Tim Unesa rencana akan dilakukan selama tiga tahun. Dalam kegiatan promosi yang dilakukan salah satunya yaitu adalah koordinator dari anggota Tim menjual produk di Tempat Wisata Pasir Putih Dalegan (WISID) pada hari-hari tertentu seperti hari minggu dan tanggal merah peringatan hari besar nasional. Sehingga Produk "Nata De Legen" mampu untuk di jangkau dan di kenal oleh wisatawan asing. Dari tim "Nata De Legen" sendiri mencoba membranding produk dengan persuasif.

Berpijak dari fenomena tersebut, peneliti berasumsi bahwa proses Branding harus dilakukan secara tepat sehingga promosi produk yang dilakukan mampu mempengaruhi konsumen dan citra produk. Maka dari itu, peneliti ingin mengetahui bagaimana Proses Product Branding "Nata De Legen" yang dilakukan oleh KLS (Kelompok Legen Shoberoh dan media apa yang digunakan oleh KLS

5 Aditya Bagas Pratama,. Kamus Lengkap Bahasa Indonesia. (Surabaya: Pustaka Media, 2006), 316.
(Kelompok Legen Shoberoh) dalam MemBranding "Nata De Legen".

\section{Kajian Pustaka}

1. Product Branding

\section{a. Pengertian Product Branding}

Brand dalam bahasa Inggris berasal dari kata burn (membakar).Istilah ini berakar dari bangsa Jerman Kuno yang membuat cap bakar, semacam stempel, untuk ternaknya dengan tujuan menandakan pemiliknya. Dalam Kamus Bahasa Indonesia, Brand/Merek berarti tanda yang dikenakan oleh pengusaha (pabrik, produsen, dan sebagainya) pada barang yang dihasilkan sebagai tanda pengenal; cap (tanda) yang menjadi pengenal untuk menyatakan nama. ${ }^{5}$

Brand merupakan salah satu bagian terpenting dari suatu produkkarena dapat menjadi suatu nilai tambah bagi produk baik itu produkyang berupa barang maupun jasa. Brand sangat erat kaitannyadengan berbagai strategi perusahaan serta mengandung janjiperusahaan untuk secara konsisten memberikan ciri, manfaat danjasa tertentu kepada pembeli. ${ }^{6}$

Menurut American Marketing mendefinisikan brand (merek) sebagai "nama, istilah, tanda, simbol rancangan, atau kombinasi diantaranya, yang dimaksudkan untuk mengidentifikasikan barang dan jasa

${ }^{6}$ Durianto, dkk, Strategi Menaklukan Pasar Melalui Riset Ekuitas dan Perilaku Merek, (Jakarta: PT. Gramedia Pustaka Utama, 2001), 2. 
dari seorang atau sekelompok penjual dan membedakannya dari barang dan jasa para pesaingnya". ${ }^{7}$

Chernatony and Riley mendefinisikan brand sebagai "mata rantai" antara aktifitas pemasaran perusahaan dan persepsi konsumen terhadap unsur-unsur fungsional dan emosional dalam pengalaman mereka dengan suatu produk dan cara produk tersebut dipresentasikan kepada mereka. ${ }^{8}$

Dalam komunikasi pemasaran baik pemasaran barang ataupunjasa, branding merupakan cara untuk membentuk hubunganemosional antara produsen dan konsumen. Kedekatan emosional iniakan mempengaruhi pemilihan dan keputusan konsumen dalammemilih sebuah brand. Kotler dan Amstrong berpendapat bahwabrand sebagai nama, istilah, tanda, simbol, desain, atau kombinasiseluruhnya, yang digunakan untuk mengidentifikasi barang atau jasayang ditawarkan sekaligus sebagai diferensiasi produk. ${ }^{9}$

Sebuah brand perlu dihidupkan keberadaannya, sehingga posisinya tidak tergantikan di benak konsumen. Brand membutuhkan pemeliharaan yang sustainable atau yang berkelanjutan dengan cara branding.

Product Branding adalah Proses untuk membangun brand yakni mendesain, merencanakan, dan

\footnotetext{
${ }^{7}$ Fandy Tjiptono, Pemasaran Jasa, (Malang: Bayumedia Publishing, 2006), 98-99.

${ }^{8}$ Fandy Tjiptono, Pemasaran Jasa, 99.

${ }^{9}$ Erna Ferrinadewi. Merekdan Psikologi Konsumen, (Yogyakarta: Graha Ilmu, 2008), 137.
}

mengkomunikasikan nama serta identitas sebuah Produk dengan tujuan membangun atau mengelola reputasi.

\section{b. Manfaat Product Branding}

Branding selalu menarik untuk dibahas karena memiliki posisi strategis dalam kaitannya untuk pemasaran produk. Para praktisi pemasaran menyadari bahwa nama brand yang kuat akan memberikan banyak implikasi pada perusahaan yang mampu membangun brand nya dengan baik akan mampu menangkal setiap serangan pesaing sehingga dapat terus mempertahankan pelanggannya.

\section{c. Konsep Product}

Menurut Kotler bahwa produk adalah segala sesuatu yang dapat ditawarkan ke suatu pasar untuk memenuhi keinginan dan kebutuhan. Dalam ISO 8402 yang dikutip Vincent Gasvers, produk adalah aktivitas atau proses. Produk dapat berbentuk (tangible) dan tak berbentuk (intangible). ${ }^{10}$

Produk dapat dilihat dari berbagai sudut pandang. Sudut pandang yang pertama adalah produk inti (core product). Produk yang menjadi alasan utama dari sebuah transaksi. Sudut pandang yang kedua adalah produk dalam pengertian yang lebih luas, artinya produk ini ditambah dengan layanan-layanan lainnya. Sudut

10 Philip Kotler, Manajemen Pemasaran, (Indonesia: PT. Macanan Jaya Cemerlang, 2002), 448. 
pandang yang ketiga adalah apabila produk dilihat dari keuntungan utama yang ditawarkan, yang disebut produk generik. $^{11}$

Dari definisi diatas, produk dapat dikatakan sebagai fokus inti dari semua bisnis. Produk adalah apa yang dilakukan perusahaan. Mulai dari mendesain produk, mengadakan sistem produksi dan operasi, menciptakan program pemasaran, sistem distribusi, iklan dan mengarahkan tenaga penjual untuk menjual produk tersebut. Bagi konsumen,produk identik dengan perusahaan. Bagi pesaing produk adalah sasaran yang harus dikalahkan.

\section{d. Atribut Produk}

Suatu produk biasanya diikuti oleh serangkaian atribut-atribut yang menyertai suatu produk meliputi beberapa hal antara lain adalah sebagai berikut: ${ }^{12}$

1) Merek

Merek adalah simbol yang dirancang untuk mengidentifikasikan produk yang ditawarkan penjual. Fungsi merek adalah untuk membedakan suatu produk perusahaan pesaingnya, untuk mempermudah konsumen mengidentifikasikan produk dan menyakinkan konsumen akan kualitas produk yang sama jika melakukan pembelian ulang.

2) Kemasan

\footnotetext{
${ }^{11}$ Ari Setiyaningrum, Jusuf Udaya, Efendi, Prinsip-prinsip Pemasaran, (Yogyakarta: Andi Offset, 2015), 89.
}

Kemasan diandalkan khusus untuk mendapatkan manfaat perlindungan dan kemudahan fungsi konsumen dalam pemasaran untuk melindungi dan menjaga keamanan produk.

3) Pemberian Label

Labeling berkaitan erat dengan pengemasan. Label merupakan bagian dari suatu produk yang menyampaikan informasi mengenai produk dan penjual. Sebuah label bisa merupakan bagian dari kemasan, atau bisa pula merupakan etiket (tanda pengenal) yang dilekatkan pada produk. Dengan demikian ada hubungan erat antara labeling, packaging, dan branding. . ${ }^{13}$

4) Layanan pelengkap

Merupakan ciri pembentuk citra produk yang sulit dijabarkan karena bersifat intangible (tidak berwujud) ini biasanya terdapat pada service atau jasa. Dewasa ini produk apapun tidak terlepas dari unsur jasa atau layanan, baik itu jasa sebagai produk inti maupun jasa sebagai pelengkap. Layanan pelengkap dapat diklasifikasikan menjadi delapan kelompok yaitu Informasi, Konsultasi, Order taking, Hospitaly, Caretaking, Exceptions, Billing, Pembayaran.

5) Jaminan produk
12 PhiliphKotler \& Kevin Lane Keller, Manajemen Pemasaran, (Indonesia : PT. Macan Jaya Cemerlang, 2007).

13 Durianto, Brand Equity Ten, (Jakarta: PT. Gramedia Pustaka Utama, 2004), 98. 
Jaminan adalah janji yang merupakan kewajiban produsen atas produknya kepada konsumen, di mana konsumen akan diberi ganti rugi bila produk ternyata tidak bisa berfungsi sebagaimana yang diharapkan atau dijanjikan. Jaminan bisa meliputi kualitas produk, reparasi, ganti rugi (uang kembali atau produk ditukar), dan sebagainya. Jaminan sendiri ada yang bersifat tertulis dan ada pula yang tidak tertulis. Dewasa ini jaminan seringkali dimanfaatkan sebagai aspek promosi, terutama pada produkproduk tahan lama. ${ }^{14}$

\section{e. Klasifikasi Product}

Klasifikasi produk bisa dilakukan atas berbagai macam sudut pandang. Berdasarkan berwujud tidaknya, produk dapat diklasifikasikan ke dalam dua kelompok utama yaitu sebagai berikut: ${ }^{15}$

1). Barang

Barang merupakan produk yang berwujud fisik, sehingga bisa dilihat, diraba/disentuh, dirasa, dipegang, disimpan, dipindahkan, dan perlakuan fisik lainnya.

2). Jasa (Service)

Jasa merupakan aktivitas, manfaat atau kepuasan yang ditawarkan untuk dijual.

\footnotetext{
${ }^{14}$ Fandy Tjiftono, Strategi Pemasaran, 88-89.

${ }^{15}$ Fandy Tjiftono, Strategi Pemasaran, 86.
}

\section{Proses Product Branding}

a. Brand Awareness

$$
\text { Kesadaran }
$$

merek

merupakan elemen ekuitas yang sangat penting bagi perusahaan karena kesadaran merek dapat berpengaruh secara langsung terhadap ekuitas merek. Apabila kesadaran konsumen terhadap merek rendah, maka dapat dipastikan bahwa ekuitas mereknya juga akan rendah. Kemampuan konsumen untuk mengenali atau mengingat merek suatu produk berbeda tergantung tingkat komunikasi merek atau persepsi konsumen terhadap merek produk yang ditawarkan. ${ }^{16}$

b. Perceived Quality

Aaker dalam Handayani mendefinisikan perceived quality sebagai persepsi konsumen terhadap kualitas atau keunggulan suatu produk atau jasa sehubungan dengan tujuan yang diinginkannya, dibandingkan dengan alternatifalternatif lain. ${ }^{17}$

Persepsi kualitas mempunyai peranan yang penting dalam membangun suatu merek, dalam banyak konteks persepsi kualitas sebuah merek dapat menjadi alasan yang penting pembelian serta merek mana yang akan dipertimbangkan konsumen yang pada gilirannya akan memengaruhi

\footnotetext{
${ }^{16}$ Aaker David. A, Manajemen Ekuitas Merek, (Jakarta: MitraUtama, 2010), 60.

${ }^{17}$ Aaker David. A, Manajemen Ekuitas, 80
} 
konsumen dalam memutuskan merek mana yang akan dibeli. ${ }^{18}$

c. Brand Association

Menurut Simamora mendefinisikan brand association sebagai segala sesuatu yang terhubung di memori konsumen terhadap suatu merek. Asosiasi merek yang positif mampu menciptakan citra merek yangsesuai dengan keinginan konsumen, sehingga dapat menciptakan rasa percaya diri konsumen atas keputusan pembelian merek tersebut. Asosiasi merek adalah segala hal yang berkaitan tentang merek dalam ingatan. asosiasi merek merupakan segala kesan yang muncul di benak seseorang yang terkait dengan ingatannya mengenai suatu merek. ${ }^{19}$

Berdasarkan definisi di atas dapat disimpulkan bahwa asosiasi merek merupakan segala hal atau kesan yang ada di benak seseorang yang berkaitan dengan ingatannya mengenai suatu merek. Kesankesan yang terkait merek akan semakin meningkat dengan semakin banyaknya pengalaman konsumen dalam mengonsumsi atau menggunakan suatu merek atau dengan seringnya penampakkan merek tersebut dalam strategi komunikasinya,

18 Durianto, dkk.Brand Equity Ten, (Jakarta: PT. Gramedia Pustaka Utama, 2004), 109.

19 Simamora, Henry, Manajemen Sumber Daya Manusia. (Yogyakarta: STIE YKPN, 2004), 63. ditambah lagi jika kaitan tersebut didukung oleh suatu jaringan dari kaitan-kaitan lain. Sebuah merek adalah seperangkat asosiasi, biasanya terangkai dalam berbagai bentuk yang bermakna. ${ }^{20}$

d. Brand Loyality

Aaker mendefinisikan bahwa brand loyality adalah sebuah ukuran ketertarikan konsumen terhadap suatu merek. Menurut Rangkuti loyalitas merek adalah satu ukuran kesetiaan konsumen terhadap suatu merek. Simamora menyatakan bahwa loyalitas merek adalah ukuran kedekatan konsumen pada sebuah merek. Loyalitas merek merupakan suatu ukuran keterkaitan seorang konsumen kepada sebuah merek. $^{21}$

Loyalitas dapat diartikan sebagai suatu komitmen yang mendalam untuk melakukan pembelian ulang produk atau jasa yang menjadi preferensinya secara konsisten pada masa yang akan datang dengan cara membeli ulang merek yang sama meskipun ada pengaruh situasional dan usaha pemasaran yang dapat menimbulkan perilaku peralihan. Loyalitas merek menunjukan adanya suatu ikatan antara pelanggan dengan merek tertentu dan ini sering kali ditandai dengan

${ }^{20}$ Durianto, dkk.Brand Equity Ten, 69.

21 Rangkuti, Freddy, Measuring Customer Satisfaction, (Jakarta: PT Gramedia Pustaka Utama, 2002), 60. 
adanya pembelian ulang dari pelanggan.

\section{Teknik Branding}

Menurut Knapp, Dalam sebuah konsep branding, yang perlu dilihat bukan hanya membuat target pemasaran kita memilih kita di dalam pasar yang penuh kompetisi namun juga membuat prospek-prospek pemasaran melihat merek (brand) kita sebagai satu-satunya yang dapat mengatasi atau memberikan solusi bagi mereka. Berdasarkan hal tersebut maka dalam membangun sebuah brand diperlukan teknik branding yang tepat diantaranya: differentiation, relevance, knowledge. ${ }^{22}$

Tidak hanya sekedar sadar (aware) terhadap brand tetapi juga memahami mengenai brand lebih mendalam, dalam arti konsumen memahami segmen dan produk atau jasa tersebut.Hal ini berarti lebih dari sekedar mengetahui nama dari brand. Ada dua aspek dari konsep knowledge, tetapi pada prakteknya kedua hal ini bekerja bersama-sama, yaitu pengetahuan tentang fungsi dan segmen brand; dan melakukan komunikasi yang kuat agar konsumen mengetahui mengenai fungsi dan segmen brand tersebut. Hal ini dapat dicapai dengan mengkomunikasikan identitas dari brand secara kuat dan

22 Duane E. Knapp, The Brand Mind set. (Yogyakarta: ANDI, 2001), 15.

${ }^{23}$ Ellwood.The Essential Brand Book :Over 100 techniques to Increase Brand Value. Second Edition, (London: Kogan Page, 2002), 211. konsisten. Knowledge bukan hanya konsekuensi dari upaya pemasaran. Publikasi dari masyarakat juga penting. Semakin banyak orang yang membicarakan brand tersebut maka semakin tinggi knowledge-nya di masyarakat, oleh karena itu knowledge merupakan suatu hal yang harus diraih oleh suatu brand. ${ }^{23}$

\section{Strategi Branding}

a) Brand Positioning

Susanto dan Wijanarko mengatakan bahwa posisi merek adalah bagian dari identitas merek dan proposisi nilai yang secara aktif dikomunikasikan kepada target konsumen dan menunjukkan keunggulannya terhadap merekmerek pesaing. ${ }^{24} \mathrm{Jadi}$ brand positioning adalah cara perusahaan untuk menempatkan dirinya di mata target konsumennya dilihat dari keunggulan dan kelebihan yang dimiliki dibandingkan dengan brand pesaing.

\section{b) Brand identity}

Gelder mengatakan, "Brand identity as a set of aspects thatconvey what a brand stands for: its background, its principles, itspurpose and ambitions", yang artinya brand identity adalah suatu kumpulan dari aspek-aspek yang bertujuan untuk menyampaikan

24 A.B Susanto \& Wijanarko, H. Power branding: Membangun merek unggul dan organisasi pendukungnya ( Jakarta: Quantum Bisnis \& Manajemen, 2004), 143. 
merek: latar belakang merek, prinsip-prinsip merek, tujuan dan ambisidari merek itu sendiri. Identitas brand adalah ciri-ciri yang diharapkan dapat melekat di benak pelanggan. Saat mendengar atau melihat brand, pelanggan akan segera mendapatkan banyak informasi mengenai brand tersebut. $^{25}$

Brand yang memiliki identitas yang kuat berarti memiliki diferensiasi yang kuat. Hal ini sangat penting untuk memantapkan eksistensi merek di pasar sehingga hubungan antara merek dan pelanggan dapat terjaga. Komponen identitas brand berupa Elemen brand itu sendiri (nama, logo, warna, jingle, desain dan kemasan, slogan dan tagline, endorser merek, karakter, situs web dan URL), Produk (jasa dan seluruh aktifitas pemasaran danprogram pemasaran pendukung), Asosiasiasosiasi lainnya yang maknanya terkait dengan brandtersebut (seseorang, suatu tempat, atau suatu peristiwa ataupengalaman tertentu). ${ }^{26}$

c) Brand personality

Kemudian menurut Crainer dan Dearlove, "Brand Personality is a brand acquires a character throught communication about the

25 Andi M. Sadat, Brand Belief (Jakarta: Salemba Empat, 2009), 48.

${ }^{26}$ Ike Janita Dewi, Implementasi dan Implikasi Kelembagaan Pemasar Pariwisata yang brand and experience of the brand and those person identified with the brand" yaitu brand personality adalah merek yang didapat dari suatu karakter melalui komunikasi tentang merk dan pengalaman dari merek serta dari orang yang memperkenalkan merk. Sedangkan menurut keller, "Brand personality is the human charasteristic or traits that can be atributed to a brand" yaitu karakteristik manusia atau ciri-ciri yang dapat diatributkan kepada suatu merek. Jadi brand personality adalah suatu cara yang bertujuan untuk menambah daya tarik dari brand dengan memberi karakteristik pada brand tadi, yang bisa didapat melalui komunikasi, pengalaman serta dari orang yang memperkenalkan brand itu sendiri. ${ }^{27}$

\section{Product Branding sebagai komunikasi pemasaran \\ Pada dasarnya merek} mengidentifikasikan perusahaan. Merek sebenarnya merupakan janji perusahaan untuk secara konsisten memberikan keistimewaan, manfaat, dan jasa tertentu kepada pembeli. Merek-merek yang terbaik memberikan jaminan mutu yang lebih baik kepada konsumen. ${ }^{28}$

Mempersiapkan dan mengembangkan suatu rencana

Bertanggung Jawab (Jakarta: Pinus Book Publisher, 2011), 35-36.

${ }^{27}$ Andi M. Sadat, Brand Belief, 51.

28 AgusHermawan, Komunikasi Pemasaran, (Jakarta: Penerbit Erlangga, 2012), 10. 
pemasaran sangatlan penting untuk mencapai tujuan yang diinginkan perusahaan atau industri. Merencanakan suatu program pemasaran memerlukan suatu analisis pasar yang mendalam. Analisis dilakukan melalui riset pasar yang akan digunakan sebagai masukan dalam proses perencanaan pemasaran. Masukan yang diterima kemudian menjadi dasar bagi pengembangan strategi pemasaran yang terkait dengan penentuan produk, harga, distribusi dan promosi. ${ }^{29}$

\section{Metode Penelitian}

Metode penelitian merupakan konsep yang digunakan untuk memperoleh data dan informasi yang terkait dalam penelitian sehingga memperoleh jawaban atas pertanyaan dari penelitian ini, metode yang ditempuh adalah metode penelitian deskriptif kualitatif. Penelitian dengan desain deskriptif kualitatif adalah bermaksud untuk memahami fenomenafenomena tentang apa yang dialami oleh subyek penelitian yang meliputi perilaku, motivasi, tindakan dan lain-lain secara holisik. Dan dengan cara deskriptif dalam bentuk kata-kata dan bahasa pada suatu konteks khusus yang alamiah dengan memanfaatkan metode alamiah. ${ }^{30}$

\section{Hasil Dan Pembahasan}

\section{Product Branding}

Pengertian dari "Product" atau "produk" sendiri adalah suatu kumpulan atribut fisik, psikis, jasa, dan sbolik yang diuat untuk memuaskan kebutuhan dan keinginan pelanggan. Sebuah produk terdiri atas atribut-atribut, baik yang mewud (intangible), termasuk kemasan, warna, harga, kualitas dan merk ditambah jasa layanan dari penjual dan reputasi. Dengan demikian, sebuah produk dapat berbentuk barang, tempat, orang, atau gagasan. Yang termasuk dalam produk adalah jasa, events, orang, tempat, organisasi, gagasan, atau campuran semua ini.

Produk merupakan segala sesuatu yang dapat ditawarkan produsen untuk diperhatikan, diminta, dicari, dibeli, digunakan, atau dikonsumsi pasar sebagai pemenuhan kebutuhan atau keinginan pasar yang bersangkutan. Secara konseptual produk adalah pemahaman subyektif dari produsen atas sesuatu yang bisa ditawarkan, sebagai usaha untuk mencapai tujuan organisasi melalui pemenuhan kebutuhan dan keinginan konsumen, sesuai dengan kompetensi dan kapasitas organisasi serta daya beli pasar.

Brand merupakan sesuatu yang tidak terlihat (intangible), tetapi efeknya sangat nyata. Brand menurut Kotler, merupakan nama atau simbol yang bersifat membedakan. Kotler juga menjelaskan bahwa brand didesain dengan

30 Burhan Bungin, Metode Penelitian Kualitatif, (Jakarta: PT.Raja Grafindo Persada, 2001), 97.
Advertising and Promotion: An Integrated marketing Communication Prespectives, (New York: 2001), 40. 
mengomunikasikan empat makna, yaitu : 1) Atribut; 2) Manfaat; 3) Nilai; 4) Kepribadian.

Chernatony and Riley mendefinisikan brand sebagai "mata rantai" antara aktifitas pemasaran perusahaan dan persepsi konsumen terhadap unsur-unsur fungsional dan emosional dalam pengalaman mereka dengan suatu produk dan cara produk tersebut dipresentasikan kepada mereka. ${ }^{31}$

Brand dalam bahasa Inggris berasal dari kata burn (membakar). Istilah ini berakar dari bangsa Jerman Kuno yang membuat cap bakar, semacam stempel, untuk ternaknya dengan tujuan menandakan pemiliknya. Dalam Kamus Bahasa Indonesia, Brand/Merek berarti tanda yang dikenakan oleh pengusaha (pabrik, produsen, dan sebagainya) pada barang yang dihasilkan sebagai tanda pengenal; cap (tanda) yang menjadi pengenal untuk menyatakan nama. ${ }^{32}$

Pada dasarnya, konsumen bukan hanya membeli sejumlah atribut ketika membeli seuah produk. Mereka sebetulnya juga membeli kepuasan terhadap keinginannya dalam bentuk keuntungan yang diharapkan akan diterima dari produk tersebut. $^{33}$ Sedangkan, Pengertian dari Brand adalah Nama, istilah, tanda, simbol, atau desain, atau kombinasi di antaranya, yang dimaksudkan untuk mengidentifikasi barang dan jasa milik seorang penjual atau sekelompok penjual dan unuk membedakannya dari milik para pesaing. ${ }^{34}$

Kemudian Branding adalah kegiatan membangun sebuah brand. Membuat

\footnotetext{
${ }^{31}$ Burhan Bungin, Metode Penelitian, 99

32 Aditya Bagas Pratama,. Kamus Lengkap Bahasa Indonesia, (Surabaya: Pustaka Media, 2006), 316.
}

identitas, termasuk logo, merupakan salah satu kegiatan branding. Branding adalah proses mendesain, merencanakan, dan mengkomunikasikan nama serta identitas dengan tujuan membangun atau mengelola reputasi. Jadi, Product Branding adalah hasil memperkenalkan branddengan cara membangun brand yakni mendesain, merencanakan, dan mengkomunikasikan nama serta identitas sebuah Produk dengan tujuan membangun atau mengelola reputasi. Product Branding bertujuan mendorong konsumen untuk bisa membedakan dan memilih produk tertentu di atas produk-produk pesaing lainnya.

Teori Komunikasi Pemasaran Terpadu atau Integrated Marketing Communication yang biasa disingkat dengan IMC oleh Don E. Scultz pada tahun 1993. IMC adalah proses pengembangan dan implementasi berbagai bentuk program komunikasi persuasif kepada pelanggan dan calon pelanggan secara berkelanjutan. Tujuan IMC adalah untuk mempengaruhi atau memberikan efek langsung kepada perilaku khalayak sasaran yang dimilikinya. IMC menganggap seluruh sumber yang dapat menghubungkan pelanggan atau calon pelanggan dengan produk atau jasa dari suatu merek atau perusahaan, adalah jalur potensial untuk menyampaikan pesan dimasa datang. Lebih jauh lagi, IMC menggunakan bentuk komunikasi yang relevan serta yang dapat diterima oleh pelanggan dan calon pelanggan dengan kata lain, proses IMC berawal pelanggan atau calon pelanggan,

\footnotetext{
${ }^{33}$ Ari Setyiyaningrum, Jusuf Udaya \& Efendi, Prinsip-prinsip, 87.

${ }^{34}$ Fandi Tjiptono, Branding \& Brand, 90.
} 
kemudian berbalik kepada perusahaan untuk menentukan dan mendefinisikan bentuk dan metode yang perlu dikembangkan bagi program komunikasi yang persuasive.

Secara sederhana-nya IMC dapat diartikan sebagai "Proses dari pengelolaan customer relationships yang menggerakkan brand value." Sedangkan secara spesifik, IMC dapat diartikan sebagai "proses yang mempunyai fungsi bersilang dalam menciptakan dan memelihara hubungan yang menguntungkan dengan customer dan stakeholder lainnya dengan mengontrol dan mempengaruhi secara strategis semua pesan yang terkirim kepada kelompok ini serta menggerakkan dialog dengan maksud tertentu kepada mereka.

Komunikasi pemasaran terpadu (IMC) merupakan proses penggunaan alat-alat promosi dalam jalur yang disatukan sehingga dapat tercipta komunikasi yang sinergis). IMC menganggap seluruh sumber yang dapat menghubungkan pelanggan atau calon pelanggan dengan produk atau jasa dari suatu merek atau perusahaan, adalah jalur yang potensial untuk menyampaikan pesan di masa datang. Lebih jauh lagi IMC menggunakan semua bentuk komunikasi yang relevan serta yang dapat diterima oleh pelanggan dan calon pelanggan. ${ }^{35}$

Komunikasi Pemasaran Terpadu pada daasarnya adalah kajian tentang suatu perusahaan memasarkan produknya melalui berbagai macam model

35 Terrence A. Shimp, Periklanan Promosi, Komunikasi Pemasaran Terpadu, (Jakarta: Erlangga, 2000), 24. komunikasi pemasaran seperti, advertising (periklanan), personal selling (penjualan tatap muka), sales promotions (promosi penjualan), public relations (humas), direct marketing (penjualanlangsung) di sertai persiapan-persiapan yang dilakukan oleh sebuah perusahaan maupun pertimbangan yang digunakan oleh sebuah perusahaan yang kesemuanya terkoordinasikan atau berintegrasi satu sama lain, sederhanya komunikasi pemasaran terpadu berfokus pada bagaimana dan apa pesan yang akan disampaikan kepada konsumen melalui berbagai media dengan isi dan inti yang sama, namun dibungkus dalam media yang berbeda demi meningkatkan Brand Value. ${ }^{36}$

\section{Dusun Shoberoh Desa Dalegan}

Desa Dalegan merupakan sebuah desa yang berada pada sebuah kecamatan Panceng, kabupaten Gresik. Batas-batas wilayah Desa Dalegan meliputi, Sebelah utara berbatasan dengan laut jawa, Sebelah timur berbatasan dengan Desa Campurejo, Desa Canga'an Kecamatan Ujung Pangkah, Sebelah selatan berbatasan dengan Desa Prupuh Sebelah barat berbatasan dengan Desa Campurejo dan Desa Banyutengah. Desa Dalegan terdiri dari 4 Dusun, yaitu Dusun Mulyorejo, Dusun Wonorejo, Dusun Shoberoh dan Dusun Larangan.

Desa Dalegan memiliki Visi yaitu "Terwujudnya Desa Dalegan Yang Demokratis, Aspiratif dan Agamis Menuju

${ }^{36}$ Philip Kotler \& Gary Amstrong, Prisipprinsip, 23. 
Desa Pendidikan Dan Wisata". Terwujudnya Desa Dalegan sebagai Desa Wisata dengan keadaan potensi alam yang berupa sumber daya alam dengan diwujudkan dalam bentuk wisata pasir putih Dalegan. Dalam pengelolaan wisata tersebut membutuhkan pengelolaan yang profesional, maka dalam pengembangan tempat wisata tersebut Pemerintah Desa bersama dengan masyarakat terus menerus mencari terobosan-terobosan baru tentang kepariwisataan sehingga menjadi wisata yang diminati publik dan terwujud Desa Wisata.

\section{Service/pelayanan dan Empati,}

Adapun dari penelitian yang telah dilakukan, peneliti mendapatkan beberapa temuan yang dapat menggambarkan tentang product branding Nata De Legen. Kelompok Legen Shoberoh berdiri pada tahun 2016, dan mulai aktif dalam pembuatan produk pada tahun 2018. KLS memberi nama produk brand-nya Nata De Legen, hal ini dikarenakan bahan bakunya adalah Legen atau nira siwalan. Sehingga tidak ada tambahan merek yang lain. Hal ini bertujuan agar masyarakat lebih mudah memahami dari arti nama Nata De Legen, yang mana merupakan hasil nira pohon siwalan merupakan hasil fermentasi dengan menggunakan mikroba Acetobacter xylinum.

Nata de legen merupakan produk unggulan daerah yang di berdayakan oleh beberapa organisasi. KLS sendiri mendapatkan ilmu dalam proses pembuatan hingga supley alat-alat produksi. Hingga saat ini peralatan yang digunakan dalam proses pembuatan adalah alat-alat dari Universitas Negeri Surabaya (UNESA), Kemudian juga bekerjasama dengan Kementrian Riset, Teknologi dan Pendidikan Tinggi Republik Indonesia (KEMENRISTEKDIKTI), kemudian dengan Dinas Kabupaten Gresik KLS mendapatkan pelatihan dan bimbingan terkait dengan izin edar.

Proses product branding terlihat ketika ada dalam sebuah event pameran dagang, seperti di Wisata Pasir Putih (WPP) Dalegan. dimana dari Kelompok Legen Shoberoh sendiri tidak menjadikan penjualan sebagai prioritas utama, tetapi lebih mengutamakan citra dari produk. Hal ini diwujudkan dengan cara pemberian tester, edukasi tentang olahan produk. Kemudian mendekati pelanggan dengan memberikan kesan yakni memberikan empati yang mampu diingat oleh konsumen. Kelompok legen Shoberoh sendiri menyadari bahwa pelanggan harus diberikan edukasi tentang produk yang telah ditawarkan.

Produk Nata De Legen belum memiliki izin edar dari Badan Pengelolahan Obat dan Makanan (BPOM), oleh karenanya produk KLS belum bisa mencantumkan Logo . Logo diterapkan di kemasan ketika Nata De Legen sudah memilik izin edar dari BPOM. Sedangkan pada saat ini masih dalam proses untuk mendapatkan izin edar. Sehingga dalam penelitian ini adalah tentang bagaimana KLS mem-branding nata de legen agar dikenal oleh masyarakat luas dan menyadari tentang adanya produk Nata de legen. Dalam hal ini KLS mengoptimalisasikan service/pelayanan dan memberikan empati kepada pelanggan 
sehingga pelanggan mampu untuk menjaga kesetiaan kepada nata de legen.

Dimulai dari tahap pengenalan hingga pemasaran, rata-rata masyarakat menerima produk nata de legen, terbukti ketika anggota kelompok legen shoberoh melakukan promosi di Facebook, beberapa orang memberikan komentar keingintahuan masyarakat terhadap produk tersebut. Sehingga pihak KLS mulai memperkenalkan dengan menggunakan tester agar masyarakat mencoba produk yang ditawarkan. Dalam optimalisasi Service/pelayanan yag dilakukan oleh KLS dalam mem-branding Nata de legen adalah memberikan pelayanan yang cepat dan tepat yakni waktu yang efisien ketika pelanggan membeli produk secara langsung maupun tidak langsung. Hal ini dikarena proses pembuatan produk yang lama sekitar 1 sampai 2 minggu maka ini adalah salah satu hal yang diperhatikan. Bersikap Sopan dan ramah kepada pelanggan sehingga pelanggan mendapatkan kenyamanan dalam proses pembelian.

Kemudian melayani komplain dari pelanggan dengan baik, seperti ketika beberapa pelanggan yang kurang suka terhadap Nata de legen. Maka pihak KLS akan melayani dengan baik dan membimbing pelanggan untuk lebih melihat manfaat yang didapat dari Nata de legen. Dalam optimalisasi Service, untuk proses pembelian secara online maka pihak KLS siap mengantarkan nata de legen ke lokasi tujuan jika di daerah kecamatan. Namun, untuk luar jangkauan kecamatan pihak KLS menggunakan jasa kurier. Untuk ketersediaan informasi tentang Nata de legen di sampaikan secara jelas mulai dari pembuatan produk, izin edar, dan masa kadalwarsa. Sehingga pelanggan mampu mencerna informasi dengan baik. Service juga berkaitan dengan harga, dalam hal ini KLS mengoptimalkan pelayanan dengan pemberian harga yang sesuai dengan pelanggan. Seperti pelanggan yang intens dalam pembelian Nata de legen dan pelanggan luar daerah.

Dalam optimalisasi Service, untuk proses pembelian secara online maka pihak KLS siap mengantarkan nata de legen ke lokasi tujuan jika di daerah kecamatan. Namun, untuk luar jangkauan kecamatan pihak KLS menggunakan jasa kurier. Untuk ketersediaan informasi tentang Nata de legen di sampaikan secara jelas mulai dari pembuatan produk, izin edar, dan masa kadalwarsa. Sehingga pelanggan mampu mencerna informasi dengan baik.

Service juga berkaitan dengan harga, dalam hal ini KLS mengoptimalkan pelayanan dengan pemberian harga yang sesuai dengan pelanggan. Seperti pelanggan yang intens dalam pembelian Nata de legen dan pelanggan luar daerah.

Dalam menjalin hubungan dan komunikasi yang baik dengan pelanggan, KLS memanfaatkan media sosial sebagai alat untuk menjalin komunikasi. Bentuk dalam menjalin hubungan dalam hal ini adalah silaturrahmi ke rumah pelanggan yang berada didaerah sekitar. Memberikan informasi jika perusahaan akan mengadakan kegiatan atau meningkatkan kualitas produk. Sehingga pelanggan merasa dihargai karena masih memberikan informasi kepada pelanggan. Seperti kegiatan dalam berkumpul di salah satu 
tempat hiburan, maka pihak KLS mengajak para pelanggan untuk ikut hadir jika berada dalam daerah tersebut.

Selain itu, KLS juga menerima kunjungan dari siswa dan siswi salah satu sekolah SMPN yang berada di Kabupaten Tuban. Tujuannya adalah untuk melakukan observasi tentang proses pembuatan nata de legen, sehingga memberikan edukasi bagi siswa dan siswi SMPN Tuban. Maka dalam hal ini, KLS juga mampu memberikan manfaat edukasi untuk masyarakat luas. Pihak KLS sendiri menerima dengan tangan terbuka sehingga memberikan pengalaman bagi pihak KLS.

Adapun optimalisasi Service, Empati merupakan salah satu hal yang mempengaruhi dalam proses branding. Dalam branding Mengembangkan rasa empati atau kepedulian penting berkenaandengan usaha menumbuhkan kesan. Rasa empati yang tinggi akan membantu kita untuk menyelaraskan pikiran dengan pelanggan, menguntungkan diri sendiri tetapi juga dapat dinikmati dan menguntungkan sesama. Sehingga mampu memberikan kenyamanan dalam berkomunikasi.

Sebagai kesediaan untuk peduli, KLS memberi perhatian pribadi bagi pelanggan. Mengenal kepribadian orang lain (pelanggan) guna menemukan keinginan yang menonjol untuk memudahkan komunikasi dalam kegiatan menghadapi pelanggan. Hal ini mengindikasikan bahwa empati adalah sebuah kondisi yang diperlukan untuk menekan sebuah hubungan positif antara dua bagian tersebut yaitu konsumen dan supplier. Untuk menekankan sebuah hubungan yang positif beberapa hal yang dilakukan KLS kepada pelanggan adalah bertanya kabar, kesibukan yang sedang dijalani. Sehingga hubungan pribadi yang dijalin akan terasa seperti persaudaraan tanpa kecanggungan dan mampu untuk memberikan manfaat untuk kelangsungan branding.

Dalam menekankan sebuah hubungan yang positif beberapa hal yang dilakukan KLS kepada pelanggan adalah bertanya kabar, kesibukan yang sedang dijalani. Sehingga hubungan pribadi yang dijalin akan terasa seperti persaudaraan tanpa kecanggungan dan mampu untuk memberikan manfaat untuk kelangsungan branding

Tujuan dari product branding ini adalah agar masyarakat mengetahui tentang produk ini, dimana Nata de legen merupakan kearifan lokal karena bahanbahan yang digunakan adalah perkembangan dari legen yang menjadi minuman favorit masyarakat sekitar. Dan nata de legen ini merupakan terobosan baru, ketika mereka yang tertarik membeli secara tidak langsung juga mereka ikut dalam memberdayakan produk dari Nata de legen. Dari mulai tahap pengenalan hingga tahap kesetiaan pelanggan, komunikasi yang dilakukan berjalan secara dua arah sehingga ada timbal balik secara langsung maupun tidak langsung. Seperti ketika memasarkan sebuah produk kepada calon pelanggan, haruslah memiliki sebuah kesan yang mampu diingat oleh calon pelanggan. Sehingga, tanpa ragu calon pelanggan ingin mencoba produk yang ditawarkan. Kesan yang juga ingin dibangun dalam hal ni adalah produk nata de legen ini merupakan produk unggulan 
yang memiliki banyak manfaat dan mampu untuk dikembangkan lebih baik lagi.

Anggota KLS juga melakukan branding secara personal, yaitu memperkenalkan nata de legen kepada orang-orang terdekat. Seperti agen legen dan juga anggota club motor, sehingga semakin membuat segmentasi pasarnya lebih luas. Mampu menjadikan nata de legen sebagai produk unggulan dan dikenal setiap kalangan masyarakat. Beberapa hambatan yang terjadi dalam proses branding ini adalah selain dari perizinan, hambatan juga timbul dari Sumber Daya Manusia (SDM) karena tidak semua anggota turut ikut dalam proses branding. Karena SDM adalah salah satu faktor dalam proses branding yang sangat dibutuhkan.

\section{Facebook sebagai Media Sosial yang Efektif}

Perencanaan dan pemilihan strategi media merupakan hal yang fundamental untuk pemilihan media yang efektif, perancangan strategi media, serta penetapan waktu untuk masing-masing media. Desain dan aplikasi media-media yang akan digunakan dan diproduksi dalam branding.Media yang digunakan adalah Whatsapp dan juga facebook. Namun yang paling efektif dan memiliki pengaruh yang cukup besar adalah Facebook. Facebookyang digunakan dalam branding adalah akun dari anggota KLS. Hal ini dikarenakan KLS sendiri belum memiliki akun facebookyang khusus untuk memasarkan nata de legen. Facebook adalah media sosial yang masih exis sampai saat ini dan masih banyak digunakan oleh masyarakat.
Mulai dari remaja hingga dewasa, facebookmudah dipelajari dan lebih diminati oleh kalangan masyarakat. Faktor lainnya adalah dari kebanyakan teman yang dimiliki adalah mereka menggunakan facebook.

Media sosial yakni Facebook adalah hal yang paling mempengaruhi product branding. Hal ini dikarenakan masyarakat mudah mendapatkan informasi tentang produk Nata de legen. Meskipun feedback yang didapat tidak secara langsung, namun beberapa dari pelanggan nata de legen adalah pengguna facebook. di media sosial, facebooklebih dominan dari whatshapp dikarenakan untuk tester dari pelanggan secara langsung terlihat dikolom komentar. Sehingga, masyarakat mampu menilai sendiri produk yang telah ditawarkan.Adapun beberapa manfaat dengan penggunaan Media sosial tersebut adalah membantu menemukan konsumen baru dan memperluas target pasar. Seperti facebook, yang membantu menemukan konsumen dan mencari konsumen yan potensial dan calon konsumen, dan dapat membagikan informasi lebih cepat. Dalam artian dapat dengan mudah membagikan informasi kepada konsumen, dan tidak memakan waktu yang lama.

\section{Kesimpulan}

Proses Product Brandingyang dilakukan oleh Kelompok Legen Shoberoh memiliki beberapa tahapan, yaitu tahap Pengenalan Produk, yakni memperkenalkan produk Nata De Legen seperti di acara Karnaval Kecamatan, Pameran Dagang dan Pameran kabupaten, Donatur acara Desa, dan Grup Personal. 
Tahap menarik konsumen, menunjukkan tentang kelebihan produk yang ditawarkan. Seperti Produk lokal yang terbuat dari Legen Murni, Memiliki khasiat dalam menyehatkan tubuh. Tahap Pemasaran Produk, Kelompok Legen Shoberoh memasarkan produk Nata De Legen secara Langsung yakni tatap muka dan melalui Media. Tahap Kesetiaan Konsumen. Pada tahap ini Kelompok Legen Shoberoh memberikan empati kepada konsumen dan memikirkan segala kepentingan pelanggan. Memberikan potongan harga, menjadikan pelanggan semakin senang dan mantap untuk membeli produk Nata de legen.

Product Branding yang dilakukan oleh Kelompok Legen Shoberoh adalah dengan Optimalisasi Service/pelayanan dan juga empati dengan komunikasi personal. Bersikap Sopan dan ramah kepada pelanggan sehingga pelanggan mendapatkan kenyamanan dalam proses pembelian. Kemudian melayani komplain dari pelanggan dengan baik. menekankan sebuah hubungan yang positif beberapa hal yang dilakukan KLS kepada pelanggan. Media yang digunakan dalam Proses Product Branding adalah Media Sosial seperti Whatsapp dan juga facebook.Kemudian titik penjualan (point of purchase) yaitu Wisata Pasir Putih Dalegan dimana skala target konsumen lebih luas karena WPP adalah tempat wisata. Dan Kelompok Legen Shoberoh juga memiliki stand di Wisata Pantai Dalegan.

\section{Daftar Pustaka}

Bungin. Burhan. Metode Penelitian Kualitatif. Jakarta: PT. Raja Grafindo Persada, 2001.

Duncan. IMC: Using Advertising and Promotion to Build Brands. New York: The McGraw-HillCompanies, 2009.

Hermawan, Agus. Komunikasi Pemasaran. Jakarta: Penerbit Erlangga, 2012.

Kotler, Philip \& Gary Amstrong. Prisipprinsip Pemasaran. Jakarta: Erlangga, 1997.

Kotler, Philip. Manajemen Pemasaran. Indonesia: Pt. Macanan Jaya Cemerlang, 2002.

Kriyantono, Rachmat. Riset Komunikasi. Jakarta: Kencana, 2006.

Limakrisna, Nandan dan Wilhelmus Hary Susilo. Manajemen Pemasaran. Jakarta: Mitra Wacana Media, 2012.

Mukhtar. Metode Penelitian Deskriptif Kualitatif. Jakarta Selatan: Referensi, 2013.

Setyiyaningrum, Ari Jusuf Udaya \& Efendi. Prinsip-prinsip Pemasaran. Yogyakarta: ANI Yogyakarta, 2015.

Tjiptono, Fandi. Branding\& Brand Longevity Indonesia. Yogyakarta: CV. Andi Offset, 2014. 